\title{
Characterization of the humoral immune response to BNT162b2 in elderly residents of long-term care facilities
} \section{five to seven months after} vaccination

Metzler $^{1}$, Eva Herrmann ${ }^{2}$, Sandra Ciesek ${ }^{1,3,4}$

1 Institute of Medical Virology, Goethe University Frankfurt, Germany

2 Institute of Biostatistics and Mathematical Modeling, Goethe University Frankfurt

3 Fraunhofer Institute for Molecular Biology and Applied Ecology (IME), Branch Translational

Medicine and Pharmacology, Frankfurt am Main, Germany

4 German Center for Infection Research, DZIF, Braunschweig, Germany.

*authors contributed equally

Corresponding author:

Sandra Ciesek, M.D.

Institute for Medical Virology

Paul-Ehrlich-Strasse 40

D-60596 Frankfurt am Main

Germany

\section{sandra.ciesek@kgu.de}

NOTE: This preprint reports new research that has not been certified by peer review and should not be used to guide clinical practice. 
The elderly residing in long-term care facilities (LTCFs) are a group at high risk for COVID-19. Hence, monitoring of the vaccine-based immunity has a pivotal role in identifying strategies to provide optimal protection in this population. We examined the immune response to the mRNA vaccine BNT162b2 against COVID-19 five to seven months after completing a two-dose regimen.

We determined significantly lower anti-SARS-CoV-2 antibody titers in 298 SARS-CoV-2 naïve residents who were at least 75 years of age (mean $51.60 \mathrm{BAU} / \mathrm{ml}$ ) (median age 87 years, range 75 to 101 years) when compared to health care workers (HCWs) aged 18 to 70 years (mean 156.99 BAU/ml, p < 0.001). Of the SARS-CoV-2 naïve residents, 29 had detectable neutralizing antibodies against the Delta variant $(9.5 \%)$, and 14 of those $(48.3 \%)$ only had a borderline titer of $1: 10$. Of 114 HCWs, 36 (31.6\%) had detectable neutralizing antibodies. In a group of 14 elderly residents who had had a PCRconfirmed breakthrough infection, the mean antibody titer was significantly higher than in the other two groups (3199.65 BAU/mL) ( $<0.001)$, and $12(85.7 \%)$ had detectable neutralizing antibodies against the Delta variant.

Our data demonstrate that $90.5 \%$ of elderly residents of LTCFs had no detectable neutralizationcompetent antibodies against the dominant Delta variant five to seven months after vaccination, and that neutralizing antibody titers were restored following a break-through infection. Our results suggest that both residents and health care workers in LTCFs would benefit from a booster vaccine six months after completing the two-dose schedule or earlier. 


\section{Introduction}

Advanced age is a strong risk factor for severe and fatal disease when infected with SARS-CoV- $2 .{ }^{1-3}$ In the elderly, in contrast to children and younger adults, coronavirus disease of 2019 (COVID-19) is rarely asymptomatic ${ }^{4}$, and respiratory failure and organ dysfunction are present in many hospitalized patients. ${ }^{5,6}$ Therefore older adults were designated a high priority to be vaccinated in the roll-out of COVID-19 vaccines. ${ }^{7}$

Due to increased exposure to the virus, living in long-term care facilities (LTCFs) further increased COVID-19-related mortality in this group of patients ${ }^{8}$. In Europe, 30 to $60 \%$ of all COVID-19-related deaths were attributed to residents of LTCFs during the early pandemic. ${ }^{9}$ Early COVID-19 vaccine studies found a high efficacy in adults ${ }^{10,11}$, but the elderly, especially with comorbidities and frailty, were commonly underrepresented or excluded. ${ }^{12}$

Waning immunity due to immunosenescence can lead to impaired immunity in these high-risk patients.13 Vaccine-induced antibodies in the elderly display lower protective capacity, and T-cell response is skewed towards short-lived effectors.14 In case of COVID-19, the vaccine is usually given to establish novel immunity rather than boosting pre-existing immunity, which is the case in most vaccines applied in the elderly. Although first real-world COVID-19 vaccine efficacy data have been favorable, efficacy against hospitalization and death was lower in those 80 years of age and older when compared to 65 to 79 years of age. ${ }^{15}$

The emergence of novel variants of concern, most recently the Delta variant, and the concerns about waning immunity against symptomatic and severe COVID-19 raised a discussion on the need for a booster shot. But there is uncertainty regarding the effect of age and frailty on immunity against severe COVID-19 after vaccination.

In this study, we sought to determine whether markers of humoral and cellular immunity differ significantly between older adults ( $\geq 75$ years of age), and a control group of health care workers (HCWs) six months after vaccination and analyzed the association of multiple variants, including medication and multimorbidity, on the immune response. 
medRxiv preprint doi: https://doi.org/10.1101/2021.11.09.21266110; this version posted November 10, 2021. The copyright holder for this

\section{Material and Methods}

\section{Recruitment of study participants and inclusion criteria}

82 This is a non-interventional observatory study. The Hessian Ministry for Social Affairs and Integration

83 commissioned this study and approached long-term care providers in Hesse with suitable

84 characteristics to participate in the study. All participants were informed about the aim of the study,

85 and written informed consent was obtained from either the study participants themselves or from

86 the legal guardian in case one had been appointed. Blood samples and data were collected at the LTC

87 facilities. Three groups of study participants were formed.

The complete two-dose schedule of BNT162b2 (Comirnaty, BioNTech/Pfizer), applied at the recommended time interval of 21 days, had to be completed five to seven months before blood collection regardless of the study group. Further inclusion criteria for study participants in the main study group (group 1) of SARS-CoV-2 naïve residents in LTCFs for the elderly included age of at least 75 years at the day of their first vaccination. All participants with a known and confirmed SARS-CoV-2 infection in the past or a positive anti-SARS-CoV-2 nucleocapsid antibody test were excluded from the main analysis. In addition, two control groups were also recruited: HCWs in LTCFs for the elderly between the ages of 18 and 70 years were recruited to the first control group (group 2). HCWs with a known SARS-CoV-2 infection in the past or a positive anti-SARS-CoV-2 nucleocapsid antibody titer were excluded. The second control group (group 3) was comprised of residents of the age of 75 years or older with a subsequent, PCR-confirmed SARS-CoV-2 breakthrough infection no earlier than 14 days after the second vaccination.

To determine whether a previous infection with SARS-CoV-2 had occurred, serum samples were tested for the presence of anti-SARS-CoV-2 nucleocapsid antibodies. We used the Abbott ARCHITECT 
medRxiv preprint doi: https://doi.org/10.1101/2021.11.09.21266110; this version posted November 10, 2021. The copyright holder for this preprint (which was not certified by peer review) is the author/funder, who has granted medRxiv a license to display the preprint in perpetuity.

All rights reserved. No reuse allowed without permission.

104 SARS-CoV-2 IgG test (Abbott Laboratories. Abbott Park, Illinois, USA). Detected antibodies may be

105 elicited after infection, but not vaccination with an mRNA vaccine.

106

Anti-SARS-CoV-2 Spike IgG Antibody Assay

107 Serum samples were tested for the presence of anti-SARS-CoV-2 Spike IgG antibodies. For this, we used the AdviseDx SARS-CoV-2 IgG II assay on the Abbott Alinity ${ }^{\oplus}$ platform (Abbott Laboratories, Abbott Park, Illinois, USA). This assay detects antibodies targeted specifically against the receptorbinding domain of SARS-CoV-2. The results are provided in standardized binding antibody units (BAU) per $\mathrm{ml}$. A result of less than $7.1 \mathrm{BAU} / \mathrm{ml}$ was considered negative, and a result of 7.1 to $8.51 \mathrm{BAU} / \mathrm{ml}$ was considered positive. Detectable antibodies may be elicited after both infection and vaccination with an mRNA vaccine.

Neutralization assay against the Delta variant

Serum samples were further analyzed for the presence of antibodies with neutralizing capacity against the Delta variant of SARS-CoV-2 (B.1.617.2) in a biosafety level 3 laboratory. The methodology of the SARS-CoV-2 neutralization assay has been described elsewhere. ${ }^{16}$

In brief, serum samples were serially diluted (1:2) and incubated with $4000 \mathrm{TCID50} / \mathrm{mL}$ of the Delta variant of SARS-CoV-2 (B.1.617.2) for one hour prior to infection of CaCo-2 cells. After 48 hours inoculation infected cells were examined for cytopathic effect (CPE) formation by light microcopy to determine the neutralization titer. 
medRxiv preprint doi: https://doi.org/10.1101/2021.11.09.21266110; this version posted November 10, 2021. The copyright holder for this preprint (which was not certified by peer review) is the author/funder, who has granted medRxiv a license to display the preprint in perpetuity.

\section{Statistical analysis}

129 Data analysis was performed using RStudio Version 1.4.1717. Mean Anti-SARS-CoV-2 spike IgG

130 antibody titers were tested for normality (Shapiro-Wilk test), and homogeneity of variance between

131 the three study groups respectively (Levene's test) The threshold for statistical significance was $\alpha<$

1320.05 in two-sided t-tests.

133 Funding source and ethical approval

134 The study was commissioned and funded by the Hessian Ministry of Social Issues and Integration.

135 The study protocol has been approved by the ethics board of the University Hospital Frankfurt (No.

136 20-864) and has been registered on the German Clinical Trial Register (DRKS00025813). 
medRxiv preprint doi: https://doi.org/10.1101/2021.11.09.21266110; this version posted November 10, 2021. The copyright holder for this preprint (which was not certified by peer review) is the author/funder, who has granted medRxiv a license to display the preprint in perpetuity.

\section{Results}

\section{Study population}

139 Samples were collected from $22^{\text {nd }}$ July to $16^{\text {th }}$ September 2021 in 16 LTCFs in Hesse, Germany.

140 Group 1: Residents of LTCFs $\geq 75$ years of age without prior infection or

\section{1 breakthrough infection}

142 A total of 298 residents of the LTCFs participated in the study and were included in group 1. $143212(71.1 \%)$ were female, 86 (28.9\%) were male, and none reported non-binary gender. The median 144 age was 86 years (range: 75 to 101 years, IQR: 82 to 90.8 years). The mean Body Mass Index (BMI) 145 was $25.6 \mathrm{~kg} / \mathrm{m}^{2}$ ranging from $14.9 \mathrm{~kg} / \mathrm{m}^{2}$ to $42.9 \mathrm{~kg} / \mathrm{m}^{2}$.

146 Group 2: HCWs aged 18 to 70 years of age 114 HCWs were included in group 2. 83 (77.8\%) were female, and 31 (27.2\%) were male. None reported non-binary gender. The median age was 53 years (range: 24 to 70 years, IQR: 45.3 to 59.8 years). The mean BMI was $26.8 \mathrm{~kg} / \mathrm{m}^{2}$ ranging from 18 to $50 \mathrm{~kg} / \mathrm{m}^{2}$. none reported non-binary gender. The mean number of days between the second vaccination and the positive PCR test result was 109 days. The earliest breakthrough infection happened 19 days, and the latest 211 days after the second vaccination. The median age was 89 years (range: 82 to 93 years, IQR: 86.3 - 91). The mean BMI was $24.24 \mathrm{~kg} / \mathrm{m}^{2}$ ranging from 17 to $32 \mathrm{~kg} / \mathrm{m}^{2}$.

Table 1 provides an overview of the study participants in all three groups.

Of the study participants in group 1 (residents $\geq 75$ years of age without known prior infection or breakthrough infection), 6 (0.02\%) had detectable SARS-CoV-2 nucleocapsid antibodies and were 
medRxiv preprint doi: https://doi.org/10.1101/2021.11.09.21266110; this version posted November 10, 2021. The copyright holder for this preprint (which was not certified by peer review) is the author/funder, who has granted medRxiv a license to display the preprint in perpetuity.

All rights reserved. No reuse allowed without permission.

161 or breakthrough infection) no participant had detectable SARS-CoV-2 nucleocapsid antibodies. In

162 group 3, which was comprised of residents with a PCR-confirmed breakthrough infection, only 4 of 16314 participants (28.6\%) had detectable anti-SARS-CoV-2 nucleocapsid antibodies.

16450 participants (16.78\%) in group 1 tested negative for anti-SARS-CoV-2 spike IgG antibodies, 9 165 (3.02\%) had a borderline positive result and 239 (80.2\%) tested positive. In the first control group of 166 HCWs (group 2), a vast majority of $97.37 \%$ (111/114) of participants tested positive. Two participants 167 tested negative, and one tested borderline positive. In the second control group of residents with a breakthrough infection (group 3), all 14 participants tested positive for anti-SARS-CoV-2 spike IgG antibodies (14/14) (figure 1).

In group 1, the anti-SARS-CoV-2 spike IgG antibody concentration had a mean of $51.60 \mathrm{BAU} / \mathrm{ml}$ (range: $0.90-710.64 \mathrm{BAU} / \mathrm{ml}$, IQR: $12.09-61.47 \mathrm{BAU} / \mathrm{ml}$ ). This was lower than in group 2, which had a mean of $156.99 \mathrm{BAU} / \mathrm{ml}$ (range: $5.61-2008.16 \mathrm{BAU} / \mathrm{ml}$, IQR: $57.04-176.29 \mathrm{BAU} / \mathrm{ml}$ ). This difference was statistically significant $(\mathrm{Cl} 95 \%, \mathrm{p}<0.001)$ (figures $1-3)$. In these groups, a linear decline with age was observed, which was more prominent in group $1(\mathrm{Cl} 95 \%, \mathrm{p}<0.001)$ (figure 1 ). In group 3, the mean antibody concentration of anti-SARS-CoV-2 RBD IgG was highest, with 3199.65 $\mathrm{BAU} / \mathrm{mL}$ (range: $58.73-11360.00 \mathrm{BAU} / \mathrm{ml}$, IQR: $857.65-4601.88 \mathrm{BAU} / \mathrm{ml}$ ). This is significantly higher than in group 1 and group 2 (Cl 95\%, $\mathrm{p}<0.001$, respectively).

Neutralizing antibodies against the Delta variant were detected in 29 study participants $(9.7 \%)$ of group 1, of which $14(48.3 \%)$ had a borderline positive titer of 1:10. In group 2, 36 participants (31.6\%) had detectable neutralizing antibodies against the Delta variant, of which 16 were borderline positive (titer of 1:10). In group 3, residents with a breakthrough infection, 12 (85.7\%) had

4). 
medRxiv preprint doi: https://doi.org/10.1101/2021.11.09.21266110; this version posted November 10, 2021. The copyright holder for this preprint (which was not certified by peer review) is the author/funder, who has granted medRxiv a license to display the preprint in perpetuity.

187 Here, we report the analysis of markers of the humoral response five to seven months after vaccination with the mRNA vaccine BNT162b2 in a group of residents of LTCFs. The SARS-CoV-2 naïve residents, aged $\geq 75$ years of age, had a significantly lower concentration of anti-RBD-antibodies than younger health HCWs (figures 2 and 3). A linear decline with age was observed in both the group of residents and HCWs but was more marked in the elderly (figure 1).

The elderly also had a smaller fraction of individuals with detectable neutralizing antibodies against the Delta variant $(9.7 \%$, figure 4$)$. Almost half $(48.3 \%)$ of this minority with detectable neutralization only exhibited a borderline positive titer of $1: 10$. While the mean anti-SARS-CoV-2 IgG antibody concentration in our control group of younger HCWs was significantly higher, neutralization against the Delta variant was also only detected in a minority of $31.6 \%$ of the participants in this group five to seven months after having completed a full series of vaccination.

A breakthrough infection vastly increased both the antibody concentration and fraction of individuals recoverability of the humoral immune response.

These data support that a booster vaccine would be beneficial in this high-risk group of patients six months or earlier after completing the two-dose schedule with an mRNA vaccine. This is in coherence with other studies in this age group, even though studies based on pseudovirus neutralization assays provided divergently higher rates of neutralization. ${ }^{17}$ A possible explanation might be that for the neutralization assays we employed an authentic Delta variant isolate ${ }^{16}$ rather than a pseudovirus. Clinical isolates harbor additional mutations outside the Spike region which can impact the viral fitness or sensitivity to antibodies in cell culture. Markers of the cellular response of the study participants are currently examined and will be published when available. These additional data may influence the interpretation of the study results. 
medRxiv preprint doi: https://doi.org/10.1101/2021.11.09.21266110; this version posted November 10, 2021. The copyright holder for this preprint (which was not certified by peer review) is the author/funder, who has granted medRxiv a license to display the preprint in perpetuity. All rights reserved. No reuse allowed without permission.

210 Since a majority of HCWs from these facilities, a group at large risk of transmitting infection to

211 vulnerable patients, also did not have detectable neutralizing antibodies against the Delta variant, a

212 booster of the humoral response appears indicated in this group as well.

213 Of the study participants in group 3, all of which had had a PCR-confirmed breakthrough infection, 214 only $28.6 \%$ had detectable anti-nucleocapsid IgG response. This highlights that infection with SARS-

215 CoV-2 in this group may occur without mounting an anti-nucleocapsid response, and some of the 216 other participants may also have had an unknown infection that went undetected. Additional 217 limitations of our study include that break-through infections in group 3 occurred at diverse time 218 points before blood samples were taken. In addition to age, immunogenicity and efficacy of vaccines 219 may be influenced and suppressed by several factors, including other medical conditions, and body 220 composition with a very low or high BMI. ${ }^{18}$

221 Analyses of these factors in our study cohort will be provided in a subsequent publication. 
medRxiv preprint doi: https://doi.org/10.1101/2021.11.09.21266110; this version posted November 10, 2021. The copyright holder for this preprint (which was not certified by peer review) is the author/funder, who has granted medRxiv a license to display the preprint in perpetuity.

\section{Tables}

226 Table 1: Characteristics of the study participants

\begin{tabular}{|c|c|}
\hline & $\begin{array}{l}\text { Participants } \\
(n=426)\end{array}$ \\
\hline Role & [\% of all participants] \\
\hline Group 1: Residents $\geq 75$ years of age & $298(70 \%)$ \\
\hline Group 2: HCWs aged 18 to 70 years of age & $114(26.8 \%)$ \\
\hline Group 3: Residents with breakthrough infection & $14(3.2 \%)$ \\
\hline Age at day of first vaccination & [median (IQR)] \\
\hline Group 1 & $86.0(82.0-90.75)$ \\
\hline Group 2 & $53.0(45.25-59.75)$ \\
\hline Group 3 & $89.0(86.25-91)$ \\
\hline Sex & [\% in each group] \\
\hline \multicolumn{2}{|l|}{ Group 1} \\
\hline Female & $212(71.1 \%)$ \\
\hline Male & $86(28.9 \%)$ \\
\hline \multicolumn{2}{|l|}{ Group 2} \\
\hline Female & $83(72.8 \%)$ \\
\hline Male & $31(27.2 \%)$ \\
\hline \multicolumn{2}{|l|}{ Group 3} \\
\hline Female & $13(92.9 \%)$ \\
\hline Male & $1(7.1 \%)$ \\
\hline BMI & [median in $\mathrm{kg} / \mathrm{m}^{2}(\mathrm{IQR})$ ] \\
\hline Group 1 & $25.3(22.4-28.6)$ \\
\hline Group 2 & $26.4(22.5-30.2)$ \\
\hline Group 3 & $23.34(20.47-28.64)$ \\
\hline Interval between second vaccination and blood draw & $\begin{array}{l}6.49(5.08-7.70) \text { [median in } \\
\text { months (range)] }\end{array}$ \\
\hline
\end{tabular}


medRxiv preprint doi: https://doi.org/10.1101/2021.11.09.21266110; this version posted November 10, 2021. The copyright holder for this preprint (which was not certified by peer review) is the author/funder, who has granted medRxiv a license to display the preprint in perpetuity. All rights reserved. No reuse allowed without permission.

\section{Figures}

231 Figure 1: Anti-SARS-CoV-2 spike IgG titer (logarithmic) by study participants' age.

232 Group 1 (residents of LTCFs $\geq 75$ years of age; orange), group 2 (HCWs at LTCFs, 18 to 70 years of 233 age; blue), group 3 (residents of LTCFs after a breakthrough infection, green). Plotted within the 234 scatter is the linear regression (lines in colors of the respective study groups) with the standard error 235 (grey areas, 95\% Cl). The red line displays the cut-off anti-SARS-CoV-2 spike IgG antibody concentration of $8.52 \mathrm{BAU} / \mathrm{ml}$, which is considered a positive test result (borderline: $7.10-8.51$ $\mathrm{BAU} / \mathrm{ml})$.

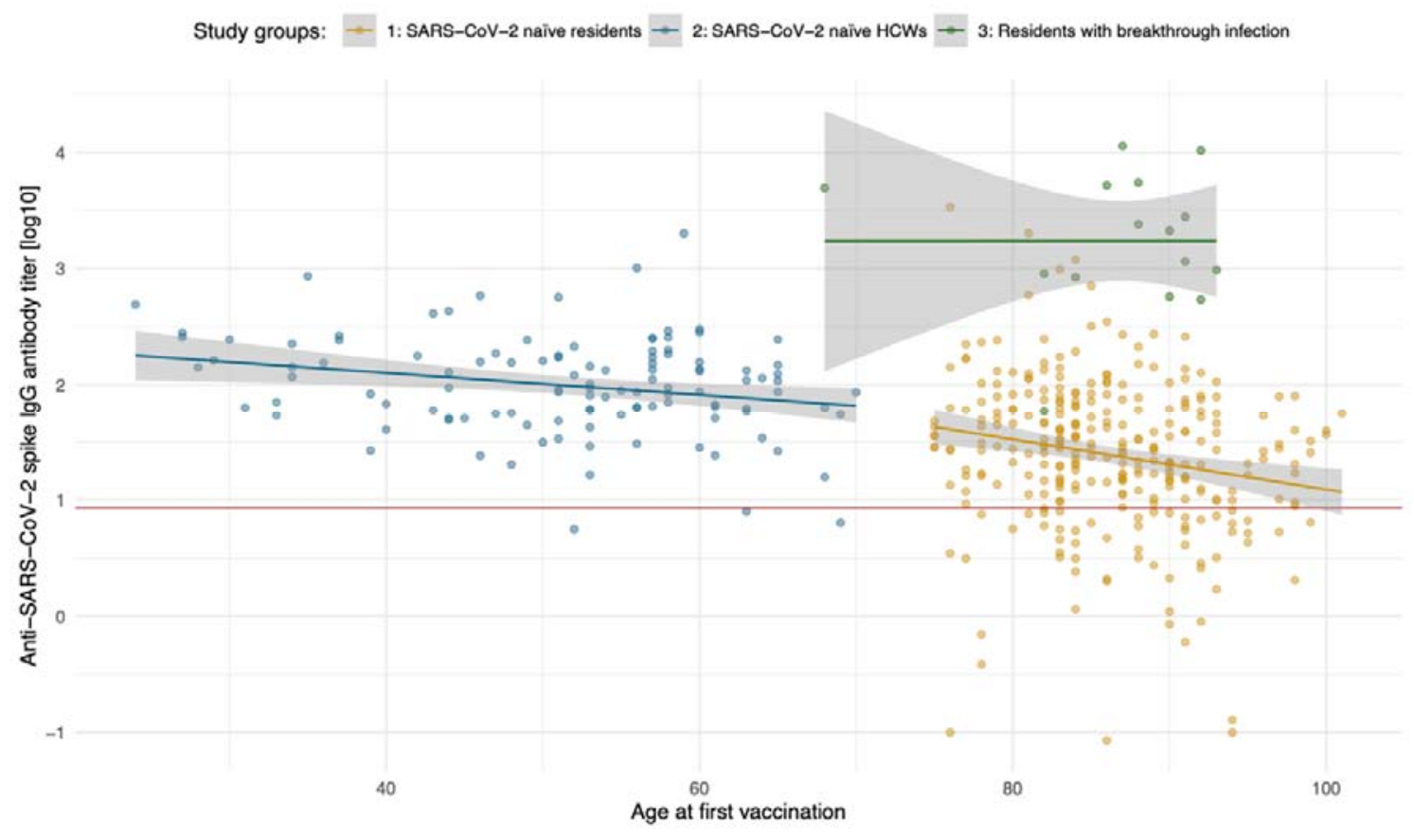


medRxiv preprint doi: https://doi.org/10.1101/2021.11.09.21266110; this version posted November 10, 2021. The copyright holder for this preprint (which was not certified by peer review) is the author/funder, who has granted medRxiv a license to display the preprint in perpetuity. All rights reserved. No reuse allowed without permission. 
medRxiv preprint doi: https://doi.org/10.1101/2021.11.09.21266110; this version posted November 10, 2021. The copyright holder for this preprint (which was not certified by peer review) is the author/funder, who has granted medRxiv a license to display the preprint in perpetuity. All rights reserved. No reuse allowed without permission.

246 Figure 2: Anti-SARS-CoV-2 spike IgG antibody titers (logarithmic) by group.

247 Logarithmic depiction in boxplots, 95\% Cl and IQR (25\%-75\%) of group 1 (residents of LTCFs $\geq 75$

248 years of age; orange), group 2 (HCWs at LTCFs, 18 to 70 years of age; blue), and group 3 (residents of

249 LTCFs after breakthrough infection, green). Stars represent outliers.

250

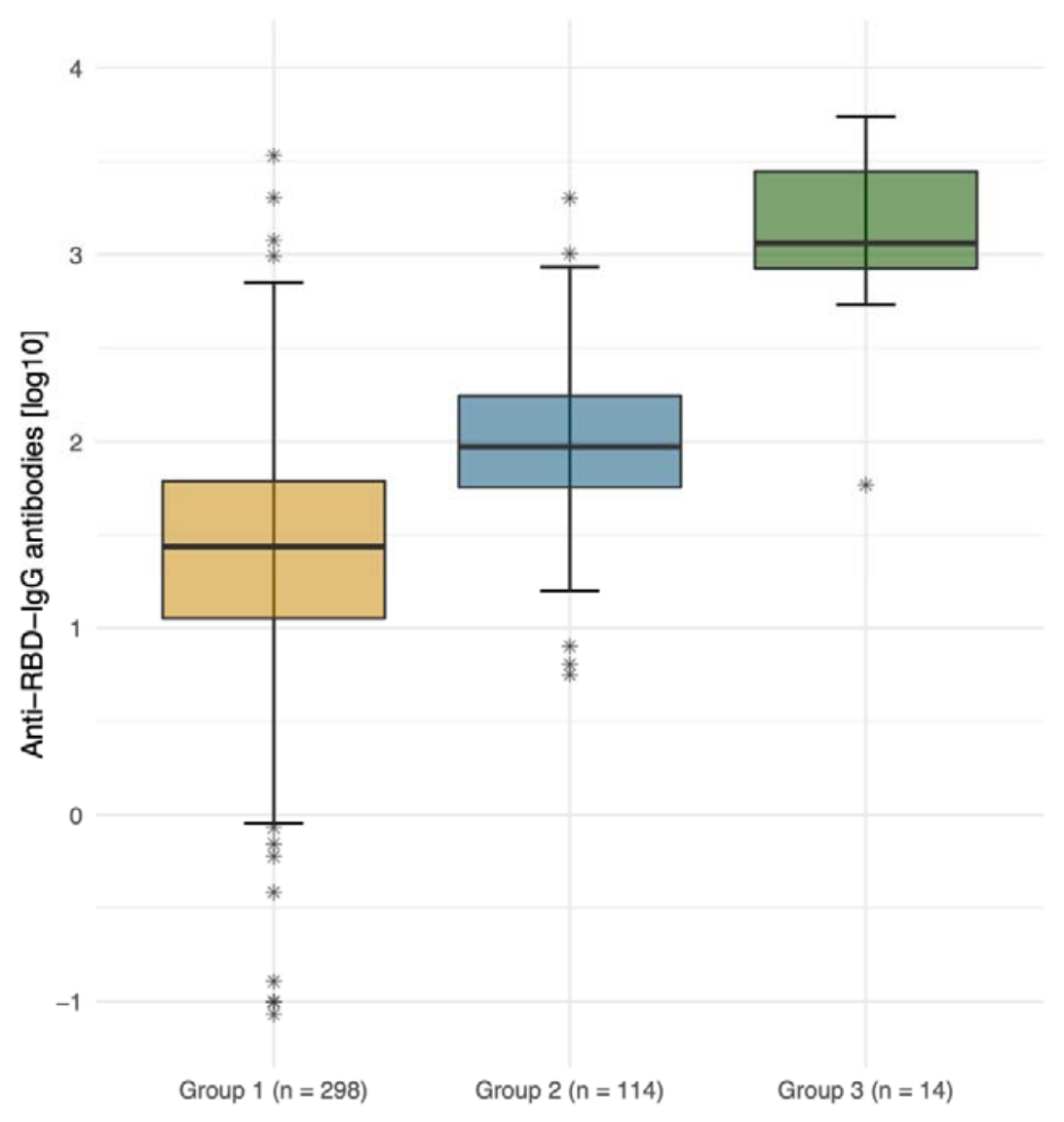

251

252

253

254

255

256

257

258

259 
medRxiv preprint doi: https://doi.org/10.1101/2021.11.09.21266110; this version posted November 10, 2021. The copyright holder for this preprint (which was not certified by peer review) is the author/funder, who has granted medRxiv a license to display the preprint in perpetuity. All rights reserved. No reuse allowed without permission.

260 Figure 3: Anti-SARS-CoV-2 spike IgG antibody titer (non-logarithmic).

261 Violin plots for visualization of differences in the distribution of anti-SARS-CoV-2 spike IgG antibody

262 titers of groups 1 (residents of LTCFs $\geq 75$ years of age; orange) and 2 (HCWs at LTCFs, 18 to 70 years

263 of age; blue). The red line displays the cut-off anti-SARS-CoV-2 spike IgG antibody concentration of

$2648.52 \mathrm{BAU} / \mathrm{ml}$, which is considered a positive test result (borderline: $7.10-8.51 \mathrm{BAU} / \mathrm{ml}$ ).

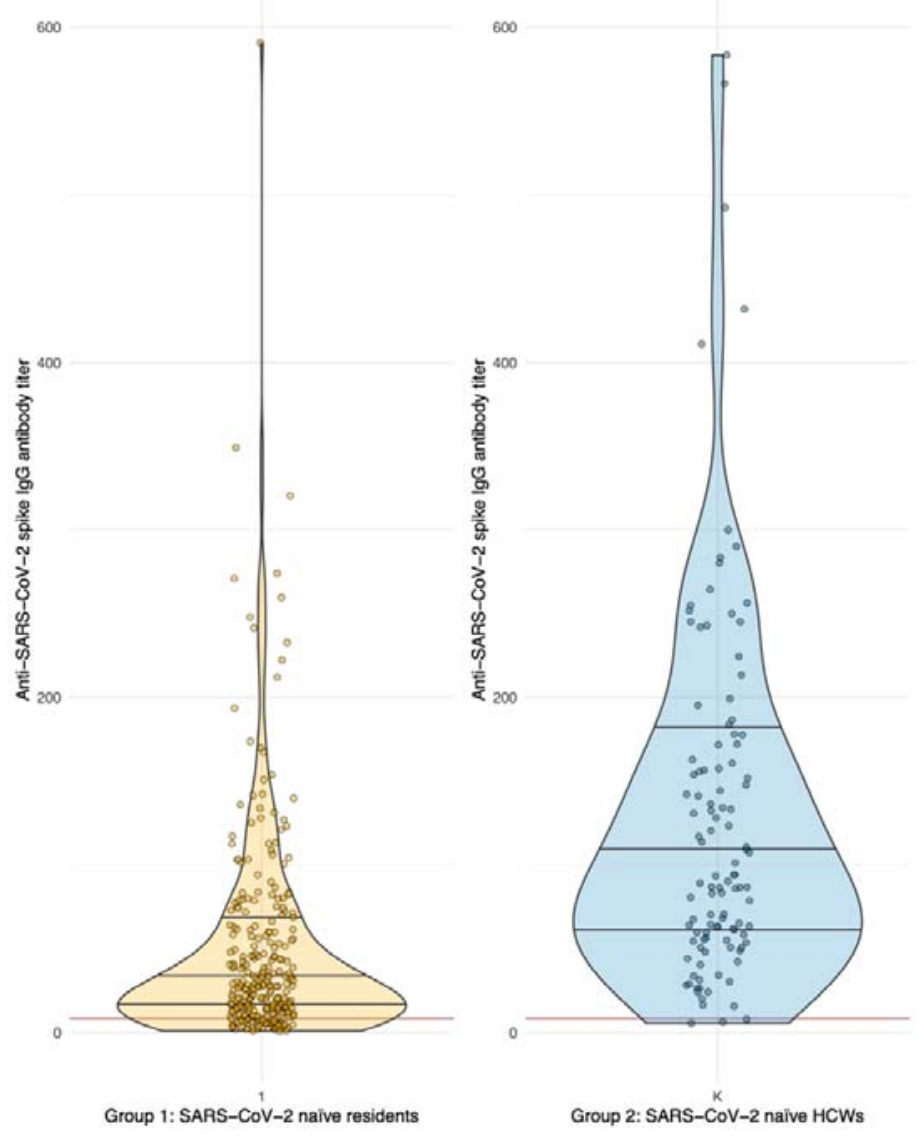


medRxiv preprint doi: https://doi.org/10.1101/2021.11.09.21266110; this version posted November 10, 2021. The copyright holder for this preprint (which was not certified by peer review) is the author/funder, who has granted medRxiv a license to display the preprint in perpetuity. All rights reserved. No reuse allowed without permission.

267 Figure 4: Barplots depicting the fraction of study participants in group 1 (residents of LTCFs $\geq 75$

268 years of age), group 2 (HCWs at LTCFs, 18 to 70 years of age), and group 3 (residents of LTCFs after breakthrough infection) who exhibit neutralization titers against the Delta variant five to seven months after receiving the second dose of an mRNA vaccine.

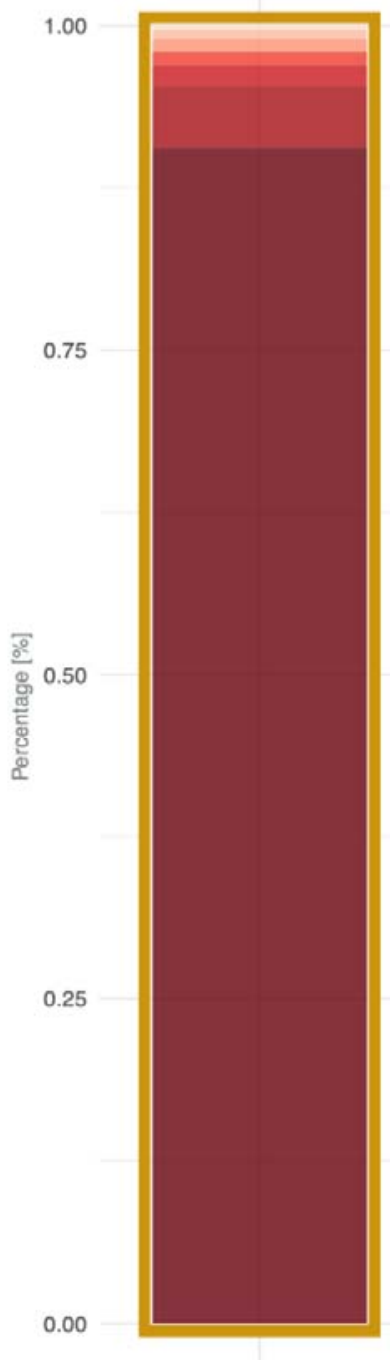

Group 1 ( $n=297)$

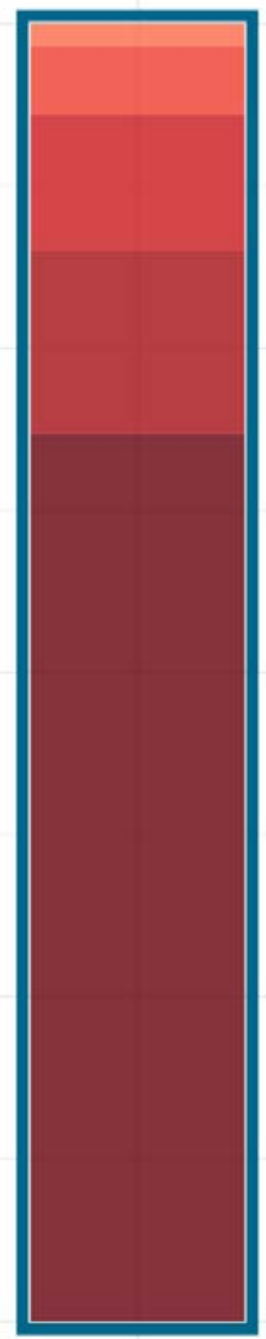

Group $2(n=114)$

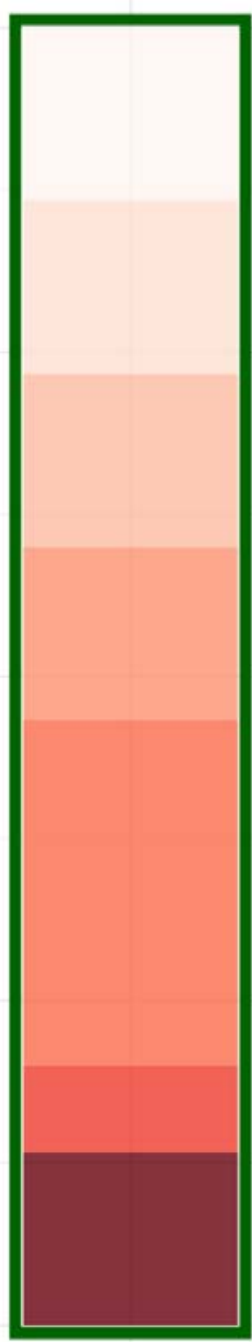

Group $3(n=14)$
Titer
$1: 1280$
$1: 640$
$1: 320$
$1: 160$
$1: 80$
$1: 40$
$1: 20$
$1: 10$
No neutralization 
medRxiv preprint doi: https://doi.org/10.1101/2021.11.09.21266110; this version posted November 10, 2021. The copyright holder for this preprint (which was not certified by peer review) is the author/funder, who has granted medRxiv a license to display the preprint in perpetuity. All rights reserved. No reuse allowed without permission.

\section{Acknowledgments}

273 The authors thank the staff of the facilities we visited, for their aid in conducting our investigation,

274 and their tireless work in the pandemic and beyond.

275 We also thank all residents and staff who donated blood for this study.

277 Potential conflicts of interest

278 S.C. received honorarium for serving on a clinical advisory board for BioNTech.

279

280 
1. Du, R.-H., Liang, L.-R., Yang, C.-Q., Wang, W., Cao, T.-Z., Li, M., Guo, G.-Y., Du, J., Zheng, C.-L., Zhu, Q., et al. (2020). Predictors of mortality for patients with COVID-19 pneumonia caused by SARS-CoV2: a prospective cohort study. Eur Respir J 55, 2000524.

2. Trecarichi, E.M., Mazzitelli, M., Serapide, F., Pelle, M.C., Tassone, B., Arrighi, E., Perri, G., Fusco, P., Scaglione, V., Davoli, C., et al. (2020). Clinical characteristics and predictors of mortality associated with COVID-19 in elderly patients from a long-term care facility. Sci Rep-uk 10, 20834.

3. Wang, Y., Lu, X., Li, Y., Chen, H., Chen, T., Su, N., Huang, F., Zhou, J., Zhang, B., Yan, F., et al. (2020). Clinical Course and Outcomes of 344 Intensive Care Patients with COVID-19. Am J Resp Crit Care 0 , 1430-1434.

4. Sah, P., Fitzpatrick, M.C., Zimmer, C.F., Abdollahi, E., Juden-Kelly, L., Moghadas, S.M., Singer, B.H., and Galvani, A.P. (2021). Asymptomatic SARS-CoV-2 infection: A systematic review and metaanalysis. Proc National Acad Sci 118, e2109229118.

5. Neumann-Podczaska, A., Al-Saad, S.R., Karbowski, L.M., Chojnicki, M., Tobis, S., and WieczorowskaTobis, K. (2020). COVID 19 - Clinical Picture in the Elderly Population: A Qualitative Systematic Review. Aging Dis 11, 988-1008. comparison with young and middle-aged patients. J Infection 80, e14-e18.

7. Organization, T.W.H. (2020). WHO SAGE values framework for the allocation and prioritization of COVID-19 vaccination. https://apps.who.int/iris/bitstream/handle/10665/334299/WHO-2019-nCoVSAGE_Framework-Allocation_and_prioritization-2020.1-eng.pdf?sequence=1\&isAllowed=y.

8. Amore, S., Puppo, E., Melara, J., Terracciano, E., Gentili, S., and Liotta, G. (2021). Impact of COVID19 on older adults and role of long-term care facilities during early stages of epidemic in Italy. Sci 305 Rep-uk 11, 12530.

306 9. Team, E.P.H.E., Danis, K., Fonteneau, L., Georges, S., Daniau, C., Bernard-Stoecklin, S., Domegan, L., 307 O'Donnell, J., Hauge, S.H., Dequeker, S., et al. (2020). High impact of COVID-19 in long-term care 308 facilities, suggestion for monitoring in the EU/EEA, May 2020. Eurosurveillance 25, 2000956. Moreira, E.D., Zerbini, C., et al. (2020). Safety and Efficacy of the BNT162b2 mRNA Covid-19 Vaccine. New Engl J Med 383, 2603-2615. 
medRxiv preprint doi: https://doi.org/10.1101/2021.11.09.21266110; this version posted November 10, 2021. The copyright holder for this preprint (which was not certified by peer review) is the author/funder, who has granted medRxiv a license to display the preprint in perpetuity. All rights reserved. No reuse allowed without permission.

317 13. Poland, G.A., Ovsyannikova, I.G., and Kennedy, R.B. (2018). Personalized vaccinology: A review. 318 Vaccine $36,5350-5357$.

319 14. Gustafson, C.E., Kim, C., Weyand, C.M., and Goronzy, J.J. (2020). Influence of immune aging on 320 vaccine responses. J Allergy Clin Immun 145, 1309-1321.

321 15. Nunes, B., Rodrigues, A.P., Kislaya, I., Cruz, C., Peralta-Santos, A., Lima, J., Leite, P.P., Sequeira, D., 322 Dias, C.M., and Machado, A. (2021). mRNA vaccine effectiveness against COVID-19-related 323 hospitalisations and deaths in older adults: a cohort study based on data linkage of national health 324 registries in Portugal, February to August 2021. Eurosurveillance 26.

325 16. Wilhelm, A., Toptan, T., Pallas, C., Wolf, T., Goetsch, U., Gottschalk, R., Vehreschild, M.J.G.T., 326 Ciesek, S., and Widera, M. (2021). Antibody-Mediated Neutralization of Authentic SARS-CoV-2 327 B.1.617 Variants Harboring L452R and T478K/E484Q. Viruses 13, 1693.

328 17. Collier, D.A., Ferreira, I.A.T.M., Kotagiri, P., Datir, R.P., Lim, E.Y., Touizer, E., Meng, B., Abdullahi, 329 A., Collaboration, T.C.-N.B.C.-19, Investigators, P., et al. (2021). Age-related immune response 330 heterogeneity to SARS-CoV-2 vaccine BNT162b2. Nature 596, 417-422.

331 18. Mitsunaga, T., Ohtaki, Y., Seki, Y., Yoshioka, M., Mori, H., Suzuka, M., Mashiko, S., Takeda, S., and 332 Mashiko, K. (2021). The evaluation of factors affecting antibody response after administration of the 333 BNT162b2 vaccine: a prospective study in Japan. Peerj 9, e12316. 